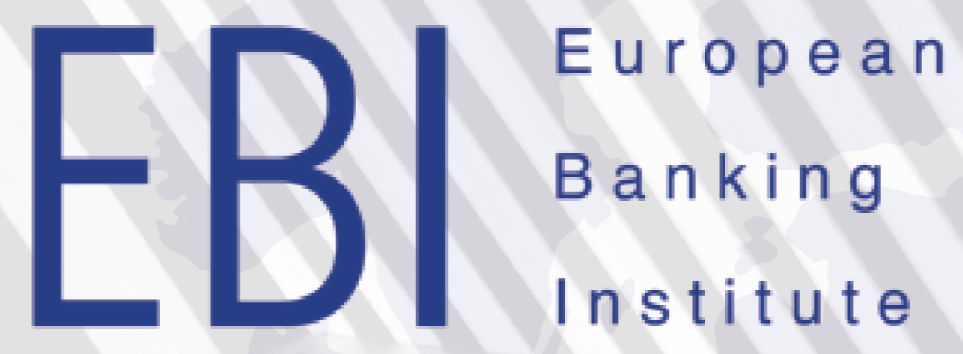

EBI Working Paper Series

2018 - no. 21

Guido Ferrarini/Davide Trasciatti

Brexit and OTC Derivatives Clearing: The Role of Politics 
The European Banking Institute based in Frankfurt is an international centre for banking studies resulting from the joint venture of Europe's preeminent academic institutions which have decided to share and coordinate their commitments and structure their research activities in order to provide the highest quality legal, economic and accounting studies in the field of banking regulation, banking supervision and banking resolution in Europe. The European Banking Institute is structured to promote the dialogue between scholars, regulators, supervisors, industry representatives and advisors in relation to issues concerning the regulation and supervision of financial institutions and financial markets from a legal, economic and any other related viewpoint. The Academic Members of EBI are the following:

1. Universiteit van Amsterdam, Amsterdam, The Netherlands

2. Universiteit Antwerpen, Antwerp, Belgium

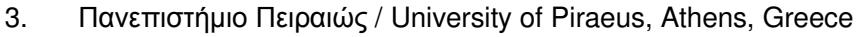

4. Alma Mater Studiorum - Università di Bologna, Bologna, Italy

5. Academia de Studii Economice din București (ASE), Bucharest, Romania

6. Universität Bonn, Bonn, Germany

7. Trinity College, Dublin, Ireland

8. Goethe-Universität, Frankfurt, Germany

9. Universiteit Gent, Ghent, Belgium

10. Helsingin yliopisto (University of Helsinki, Helsinki, Finland)

11. Universiteit Leiden, Leiden, The Netherlands

12. Universidade Católica Portuguesa, Lisbon, Portugal

13. Universidade de Lisboa, Lisbon, Portugal

14. Univerze v Ljubljani / University of Ljubljana, Ljubljana, Slovenia

15. Queen Mary University of London, London, United Kingdom

16. Université du Luxembourg, Luxembourg

17. Universidad Autónoma Madrid, Madrid, Spain

18. Universidad Complutense de Madrid/CUNEF, Madrid, Spain

19. Johannes Gutenberg University Mainz (JGU), Mainz, Germany

20. University of Malta, Malta

21. Università Cattolica del Sacro Cuore, Milan, Italy

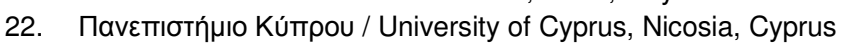

23. Radboud Universiteit, Nijmegen, The Netherlands

24. Université Panthéon - Sorbonne (Paris 1), Paris, France

25. Université Panthéon-Assas (Paris 2), Paris, France

26. Stockholms Universitet/University of Stockholm, Stockholm, Sweden

27. Tartu Ülikool / University of Tartu, Tartu, Estonia

Supervisory Board of the European Banking Institute:

Thomas Gstaedtner, President of the Supervisory Board of the European Banking Institute

Enrico Leone, Chancellor of the European Banking Institute

\section{EBI Working Paper Series}

EBI Working Paper Series are a project of the European Banking Institute e.V.. EBI Working Paper Series represent a selection of academic researches into the area of banking regulation, banking supervision and banking in general which have been drafted by professors and researchers of EBI Academic Members and selected by the Editorial Board.

\section{Editorial Board}

T. Bonneau, D. Busch, G. Ferrarini, P. Mülbert, C. Hadjiemmanuil, I. Tirado, T. Tröger, and E. Wymeersch. 


\title{
Brexit and OTC Derivatives Clearing: The Role of Politics
}

\author{
Guido Ferrarini \\ University of Genoa, Centre for Law and Finance, and University of Nijmegen
}

Davide Trasciatti

University of Genoa, Centre for Law and Finance

Abstract: In this paper, we argue that a drastic impact of Brexit on UK CCPS should in principle be avoided, for the simple reason that they have so far provided efficient clearing services to counterparties located in other EU countries, so that their disruption would not be in the interest of Europe as a whole. Nonetheless, we do not go as far as arguing that the relocation of part of the OTC derivatives clearing which presently occurs in London to other EU countries should be avoided as certainly inefficient. While believing that clearing efficiency would be optimized through concentration of the clearing services in a small number of clearing houses, we acknowledge that the information presently available on the EU clearing economy does not always support the status quo. We also admit that a relocation of part of the clearing business to other EU financial centres could be efficient in the long-run if given conditions materialize, such as the shifting of a substantial mass of derivatives transactions to one or more CCPs in the Continent at a reasonable cost. We further argue that EU and national politics could determine an impact of Brexit on OTC derivatives' clearing that is disruptive of the status quo without bringing net social benefits. Indeed, the protection of national interests and local constituencies could prevail over an informed view of the efficiency and stability of the clearing industry, which would imply leaving the choices to be made in one direction or the other to market participants. 
As a policy solution, we advocate a reform of EMIR strengthening the supervision of CCPs, including those located in third countries, along the lines recently proposed by the European Commission. Nevertheless, we suggest some amendments to the Commission's proposal that are directed to avoid the disruption of the clearing industry which would be caused by the proposed regulatory requirements. A similar reform would entitle not only ESMA and the national competent authorities, but also the central banks of issue, the ECB in particular, to effectively supervise third-country CCPs and protect the financial stability of the Union. Moreover, the central banks of issue would be able to provide liquidity to CCPs and their clearing members, particularly in stress situations. However, we advocate a clearer recourse to substitute (or comparative) compliance for third country CCPs and reject the idea of a location requirement that under the Commission's proposal could be imposed to third country CCPs in extreme circumstances.

Keywords: Brexit, OTC derivatives, Clearing, Central Counterparties, CCP, Equivalence, Financial Markets, Location policy, Trade agreement

JEL Classification: G18, G20, G23, G28 


\section{Paper's aim and scope}

Brexit will have a significant impact on OTC derivatives clearing, which is presently performed mainly in London also for derivatives in euro. EU counterparties will not be able to clear their transactions with UK CCPs anymore after Brexit, unless the latter are swiftly recognised as equivalent under EMIR or a trade agreement is made between the EU and the UK covering also financial services. However, these possibilities will be strongly influenced by politics, which could either negatively interfere with the recognition of UK CCPs as equivalent to the EU ones or make the conclusion of a trade agreement impossible. Some national governments will indeed try to create hurdles to the clearing of transactions with EU counterparties in London in order to favour the clearing houses located in their jurisdictions. Moreover, the EU central banks of issue - the European Central Bank in particular - could withdraw or modify their willingness to support euro-derivatives' clearing in London through liquidity swap agreements with the Bank of England once the UK has become a third country.

In this paper, we argue that a drastic impact of Brexit on UK CCPs should in principle be avoided, for the simple reason that they have so far provided efficient clearing services to counterparties located in other EU countries, so that their disruption would not be in the interest of Europe as a whole. Nonetheless, we do not go as far as arguing that the relocation of part of the OTC derivatives clearing which presently occurs in London to other EU countries should be avoided as certainly inefficient. While believing that clearing efficiency would be optimized through concentration of the clearing services in a small number of clearing houses, we acknowledge that the information presently available on the EU clearing economy does not always support the status quo. We also admit that a relocation of part of the clearing business to other EU financial centres could be efficient in the long-run if given conditions 
materialize, such as the shifting of a substantial mass of derivatives transactions to one or more CCPs in the Continent at a reasonable cost.

We further argue that urgent reform is needed in order to have a regulatory framework in place which is able to support either the maintenance of the status quo after Brexit or the relocation of clearing activities to the EU financial centres, under conditions of relative neutrality from a regulatory and supervisory standpoint. Indeed, the decisions as to whether to leave a leading role to UK CCPs or fragment the clearing markets by separating the transactions with EU counterparties from the others should be taken by market participants on the basis of considerations other than those concerning the impact of supervision, mainly focussing on the direct and indirect transaction costs of clearing. Similar considerations apply to UK CCPs and their corporate groups, which should be free to either keep their clearing activities in London or move the same to their EU subsidiaries under the rules applicable in the relevant Member States.

In order to analyse the first argument suggested above, we rely on the economics of clearing and the observation of the present structure and efficiency of the relevant industry (sec. 2). We then argue that EU and national politics could determine an impact of Brexit on OTC derivatives' clearing that is disruptive of the status quo without bringing net social benefits. Indeed, the protection of national interests and local constituencies could prevail over an informed view of the efficiency and stability of the clearing industry, which would imply leaving the choices to be made in one direction or the other to market participants (sec. 3). As a policy solution, which is protective of the freedom of market participants, while reinforcing the European institutions' powers relative to UK CCPs, we advocate a reform of EMIR strengthening the supervision of CCPs, including those located in third countries, along the lines recently proposed by the European Commission. Nevertheless, we suggest some amendments to the Commission's proposal that are directed to avoid the disruption of the 
clearing industry which would be caused by the proposed regulatory requirements (sec. 4). A similar reform would entitle not only ESMA and the national competent authorities, but also the central banks of issue, the ECB in particular, to effectively supervise third-country CCPs and protect the financial stability of the Union. Moreover, the central banks of issue would be able to provide liquidity to CCPs and their clearing members, particularly in stress situations. However, we advocate a clearer recourse to substitute (or comparative) compliance for third country CCPs and reject the idea of a location requirement that under the Commission's proposal could be imposed to third country CCPs in extreme circumstances. These are also our main conclusions (sec. 5).

\section{Status quo v. Relocation}

2.1 The economics of clearing have recently garnered much attention from scholars and market participants, while becoming more relevant also from a regulatory standpoint. ${ }^{1}$ To put it briefly, a CCP is a financial market infrastructure that interposes itself between trade counterparties through novation. It takes on and concentrates the risk of non-performance of the trades in the cleared market, while diminishing the mass of exposures of the aggregate market's participants thanks to multilateral netting. The economies of scale and scope of clearing favour the incumbent providers with respect to new entrants. Hence, the

\footnotetext{
1 The scholarly interest for CCPs has increased substantially as a result of the G20 reforms. A fundamental question pertains to the effectiveness of central clearing in mitigating systemic risk: see, amongst others, Darrel Duffie and Haoxiang Zhu 'Does a Central Clearing Counterparty reduce Counterparty Risk?' (2011) Review of Asset Pricing Studies 1(1), 74; Craig Pirrong 'A Bill of Goods: Central Counterparties and Systemic Risk' (2014) Journal of Financial Market Infrastructures 2(4), 55; Mark J. Roe 'Clearinghouse Overconfidence' (2013) California Law review 101, 1641. More recently, scholars focused on new trends shaping the clearing industry: see Arshadur Rahman 'Over-The-Counter (OTC) Derivatives, Central Clearing and Financial Stability' (2015) Bank of England Quarterly Bulletin Q3; Dietrich Domanski, Leonardo Gambacorta and Cristina Picillo 'Central Clearing: Trends and Current Issues'(2015) BIS Quarterly Review December 2015. For an analysis of the systemic implications of CCPs clearing, see: Guido Ferrarini and Paolo Saguato 'Regulating Financial Market Infrastructures' in Niamh Moloney, Eilis Ferran, and Jennifer Payne (eds) The Oxford Handbook on Financial Regulation (Oxford: OUP, 2016) and Paolo Saguato 'When Skin in the Game is not Enough: The Remutualization of Systemically Important Financial Market Infrastructures' (2016), available at https://ssrn.com/abstract=2810818, forthcoming in Yale Journal on Regulation.
} 
consolidation of clearing in a few CCPs lowers transaction costs significantly, whereas fragmentation across multiple CCPs delivers a suboptimal outcome in terms of market efficiency. $^{2}$

CCPs are therefore incentivized to widen their offerings and provide clearing across different products, asset classes - such as repos and fixed income - and currencies, so as to exploit netting and collateral efficiencies. They often transact in foreign currencies more than in the reference currency, for clearing is naturally transnational and many of their clients are domiciled abroad and not subject to the CCP's lex fori. ${ }^{3}$ Moreover, they are remarkably concentrated notwithstanding the high volume of contracts cleared by the relevant CCPs, as shown by recent market surveys. ${ }^{4}$

The concentration dynamics and the increasing globalization of the clearing industry carry financial stability implications, as the partial or total failure of a CCP would no doubt cause a major financial disruption in the cleared market, with spill-over effects to interconnected ones. Therefore, it is not surprising that after the 2008 financial crisis CCPs have undergone far reaching regulatory initiatives in Europe and worldwide. ${ }^{5}$ Post-crisis

\footnotetext{
2 Fragmentation of clearing across multiple CCPs strongly reduces the positive effects of central clearing: see Darrel Duffie and Haoxiang Zhu 'Does a Central Clearing Counterparty reduce Counterparty Risk?' (2011) Review of Asset Pricing Studies 1(1), 74.

3 See ESMA, 'Derivatives Markets - a first time overview', Report on trends, risk and vulnerabilities No. 2/2017, ESMA50-165-421EU, at 4, available at: https://www.esma.europa.eu/document/eu-derivatives-markets\%E2\%94\%80-first-time-overview . The report delivers the first European analysis of the 0TC interest rate swap market, which represents the predominant asset class of derivatives in terms of gross notional amount outstanding. In 2015, half of the reported transactions involved a counterparty based neither in an EU, nor in an EEA jurisdiction.

4 Buy-side concentration appears to be an inherent feature of derivatives trading, characterizing derivatives brokers since before the 2008 financial crisis: see Commission, Impact Assessment accompanying the document Proposal for a Regulation of the European Parliament and of the Council amending Regulation (EU) no 1095/2010 establishing a European Supervisory Authority and amending Regulation (EU) No 648/2012 as regards the procedures and authorities involved for the authorisation of CCPs and the requirements for the recognition of third-country, $\operatorname{COM(2017)~} 331$ final, $18 \mathrm{f}$. (in the following: Impact Assessment); see also FSB, Analysis of Central Clearing Interdependencies, Key finding no. 2, available at: https://www.bis.org/cpmi/publ/d164.htm.

5 In 2012, the European Parliament and the Council adopted the Regulation (EU) No 648/2012 of the European Parliament and of the Council on OTC derivatives, central counterparties and trade repositories [2012] 0J L201/2 (in the following: EMIR), which dictates the organizational, prudential and supervisory framework applicable to central counterparties.
} 
financial regulation reflects a common set of principles issued by the FSB and IOSCO. ${ }^{6}$ A second wave of reforms has focused on new areas, such as the framework on CCPs' recovery and resolution.7 Moreover, Brexit is stimulating a review of EMIR by the EU Commission, which is intended to improve the supervisory framework of CCPs either domiciled in the EU or in third countries. ${ }^{8}$

2.2 As already stated, the clearing industry is characterized by market concentration, which lowers the indirect costs falling on market participants and end-users. ${ }^{9}$ In Europe, the market for OTC derivatives clearing is concentrated in a UK based CCP, which services more than the $95 \%$ of the European OTC market, leaving small room for competition by either third-country or EU domiciled providers. ${ }^{10}$ Moreover, the City of London is host to a variety of ancillary services that benefit the overall dynamics of financial markets and of OTC

\footnotetext{
6 See CPSS/IOSCO “Principles for Financial Market Infrastructures" 2012 (in the following: PFMI).

${ }^{7}$ The implementation of an ad hoc recovery and resolution framework for CCPs, similarly to that already in place for the banking sector, is one of the hottest issues, both at national and international levels. In 2014, the Financial Stability Board (FSB) amended its key attributes of effective resolution regimes for financial institutions, including specific guidance on the resolution of FMIs: see FSB, 'Key Attributes of Effective Resolution Regimes for Financial Institutions' (2014) <http://www.fsb.org/wp-content/uploads/r_111104cc.pdf> (accessed 14 July 2017). Similarly, the Bank for International Settlements (BIS) committees have recently issued a consultative report concerning the recovery of CCPs, which gives a more granular description of the related PFMI principles: see CPSS \IOSCO, 'Resiliency and Recovery of Central Counterparties: Further Guidance on the PFMI' (2016) <http://www.bis.org/cpmi/publ/d149.htm> (accessed 14 July 2017). At European level, the Commission has recently published a 'Proposal for a Regulation of the European Parliament and of the Council on a Framework for the Recovery and Resolution of Central Counterparties and amending Regulation (EU) No 1095/2010, (EU) No 648/2012, and (EU) 2015/2365' COM (2016) 0856 final, COD (2016) 0365 final 28.11.2016.

8 We critically discuss the recent proposal for a regulation amending EMIR in sec. 4 below.

${ }^{9}$ See Duffie and Zhu (n. 3). This finding is also confirmed by the industry, which offers various examples of CCPs mergers. The possibility to link the derivatives CCPs of the London Stock Exchange Group and Deutsche Börse AG, with ensuing gains in terms of scale efficiencies, was one of the main drivers of the planned (but failed) merger between the two financial market infrastructures group in 2016: see Philip Strafford 'Rationale behind LSE-Deutsche Börse Deal finally works' (23 February 2016), Financial Times.

10 The numbers behind the UK derivatives market are staggering, as reported by the EC: "The UK currently plays a key role in providing clearing services in Europe (e.g. 75\% of interest-rate OTC derivatives denominated in euro are currently cleared in the UK, with a daily turnover of $\$ 574$ billion, and $\$ 77$ billion of margin to be held against these cleared trades; there is a notional outstanding volume of EUR 84.3 trillion in LCH Swapclear alone). In terms of trading alone the last triennial BIS survey shows that for the EU27 currencies such as the euro, the Polish Zloty or the Swedish Krona, more than $80 \%$ of transactions in interest-rate derivatives take place in the UK." Commission, Impact Assessment (n. 7), 48.
} 
derivatives clearing in particular, like a solid market for Repo transactions, which support the funding and collateral needs of OTC derivatives clearing members. ${ }^{11}$

Given the present concentration of the OTC derivatives market in the City and the relevant colocation benefits relative to other financial services, fragmenting the OTC derivatives industry post-Brexit would likely increase transaction costs, as important netting and collateral efficiencies would be lost. Market participants and end-users would be negatively impacted as a result, while the purported financial stability benefits would appear dubious at least. As recently shown by $\mathrm{ESMA}^{12}$ and the $\mathrm{FSB}^{13}$ in thought-provoking surveys, CCPs are linked amongst them through clearing members and common providers of ancillary services. Indeed, a dozen of large banking groups and relevant subsidiaries are active in OTC derivatives trading and provide services to CCPs, including liquidity provision, custodianship services, cash and collateral management, in highly interconnected networks of bilateral interdependencies. ${ }^{14}$ In each network, peripheral members and CCPs may be affected by events regarding entities located at the centre of the network. ${ }^{15}$

\footnotetext{
11 Given the various capital buffers, such as margins payments and default fund contributions, which compound the CCP's default waterfall, clearing is without doubt a capital intensive activity. Therefor, adequate funding channels are crucial for the functioning of the CCP clearing mechanism. As we will briefly note in the following, the repo market acts currently as an important funding source for market participants.

${ }^{12}$ At the time of publication of the results of the first ESMA's stress test regarding CCPs in 2016, the authority noted "that significant parts of CCPs collateral are pooled resources of non-defaulting CMs. In extreme cases, these CMs could face significant losses which in turn could trigger the default of further CMs and additional losses at CCP level. Therefore, ESMA recommends that CCPs incorporate in their creditworthiness assessment of CMs, the potential exposures these may face due to their membership in other CCPs. Such analysis is essential in order to identify sources of increased exposure": https://www.esma.europa.eu/press-news/esma-news/esmapublishes-results-eu-central-counterparties-stress-test

${ }^{13}$ In 2017, the FSB issued a Report including the results of the first analysis of central clearing interdependencies and highlighting that in many cases "CCP membership is drawn from a common group of large banks, which in addition to contributing to pre-funded financial resources, are also important providers of financial services to CCPs... These interdependencies are very often cross-border." FSB (n. 7), 2. Further empirical work in this area, aimed at mapping the scope of the interconnections between CCPs, clearing members and other financial entities that provide critical financial services would be relevant, in order to eventually identify possible channels of systemic risk contagion.

14 FSB (n. 7), 2.

15 However, already before the crisis some scholars vibrantly argued that the migration from bilateral to central clearing would not break the interconnections amongst incumbent financial institutions: See Pirrong (n. 2) and Roe (n. 2).
} 
2.3 The city-centricity of European OTC derivatives clearing has traditionally raised perplexities from European supervisory authorities, leading to the well-known "location policy" controversy between the ECB and the UK government. By requiring CCPs that clear large amounts of euro-denominated contracts to be established in the Eurozone, the ECB directly challenged the clearing infrastructures domiciled outside the Eurozone, particularly in London. ${ }^{16}$ The UK government brought an action against the ECB lamenting that the latter lacked the powers for enacting a similar policy and the ECJ ruled in favour of the plaintiff. ${ }^{17}$ However, the question was solved in practice through the adoption of EMIR, which filled the regulatory and supervisory gaps regarding CCPs. The ECB and the Bank of England acknowledged the ECJ ruling in a joint statement, where they also committed to foster bilateral cooperation and information exchange in respect of CCPs. ${ }^{18}$

EMIR's single rulebook and a strong culture of supervisory cooperation have proven insofar to be a reasonable framework for addressing the financial stability concerns raised by the location of most CCPs in the UK. ${ }^{19}$ Throughout the years, UK authorities have decently performed their supervisory tasks in respect of CCPs, garnering greater expertise as to intercontinental CCPs than that available in any other Member State. ${ }^{20}$ In addition, after the location policy judgement of the ECJ, the ECB and the Bank of England have consolidated their

\footnotetext{
16 The ECB claimed to have regulatory powers over CCPs in light of the provisions of Art 127(1) and (2) of the TFEU and in light of Art 22 Protocol (4) Statute of the European System of Central Banks and of the European Central Bank ( ESCB Statute) of the TFEU.

17 Judgement of the General Court of 4 March 2015 - United Kingdom vs European Central Bank T-496|11 0J C 340, 19.11.2011 location policy. See Heikki Marjosola, 'Missing Pieces in the Patchwork of EU Financial Stability Regime? The Case of Central Counterparties' (2015) 52(6), Common Market Law Review, 1491.

18 Following the T-496|11 case, the ECB and the BoE released a joint statement concerning the framework of the future central banks' relations: see European Central Bank and Bank of England Announce Measures to Enhance Financial Stability in Relation to Centrally-Cleared Markets (29 march 2015), available at: https://www.ecb.europa.eu/press/pr/date/2015/html/pr150329.en.html.

19 UK authorities took many times the lead as pathfinders for future EU regulatory strategies, as shown by the proposed rules for CCP recovery and resolution: see infra (n. 107)

${ }^{20}$ In compliance with the provisions regarding international cooperation embedded in the PFMI ( see PFMI (n. 9), Responsibility E) the UK supervisory authority has voluntarily set up global colleges, which transpose the EMIR idea on a global level, bringing at the same table supervisors from both side of the Atlantic: Bank of England, 'The Bank of England's Supervision of Financial Market Infrastructures-Annual Report' (2016), 13 available at: https://www.bankofengland.co.uk/-/media/boe/files/annual-report/2017/supervision-offinancial-market-infrastructures-annual-report- 
cooperation in the oversight of CCPs through a bilateral swap line, which enables them to mutually support the liquidity needs of relevant CCPs at any time. ${ }^{21}$ No doubt, the central banks' support is essential to the safe and orderly functioning of UK clearing infrastructures, and enhances the wider public's confidence. ${ }^{22}$

The main lesson drawn from the experience so far is that whether a CCP is located in the Eurozone or in the EU is not too relevant from a financial stability perspective, once effective supervisory arrangements are in place. In the case of CCPs located in a third country, a similar conclusion applies if the latter country has a regulatory and supervisory system in place which is equivalent to that applicable to CCPs located in a Member State and European authorities are empowered to recognize and supervise third-country CCPs. ${ }^{23}$ This conclusion is supported by the original G20 commitment and further detailed in the PFMI, which recommend a cooperative approach by supervisors to cross-border financial markets infrastructures. ${ }^{24}$

2.4 Losing single market access would cause substantial value destruction to UK CCPs, given that a large share of their clearing revenues are paid by EU authorised and domiciled

\footnotetext{
${ }^{21}$ See supra (n. 23). This cooperative solution was built on the experience of the 2008 financial crisis, where central banks established temporary liquidity swap arrangements amongst them. The importance of arrangements providing liquidity support for non-euro Member States was also reaffirmed in the European council agreement of February 2016: Angus Armstrong, 'EU Membership, Financial Services and Stability', (2016) National Institute Economic Review 236(1).

22 Interestingly, EMIR does not touch on the issue whether CCPs should be entitled to access central bank's services. The Regulation's silence is however puzzling, as access to central bank liquidity is important for a CCP's creditworthiness. Uneven access requirements across Member States may pose a direct threat to the idea of a strong level playing field embedded in EMIR. To be true, the regulation includes this topic among those which should be subject to an assessment, and possibly a review: see Art. 85 (1) EMIR. Nevertheless, during the Commission's review process, when asked about the introduction of a European mandatory requirement the ESCB expressed a negative opinion, highlighting the adequacy of the actual legal framework. The central banks' network emphasized the importance of central banks' discretion in granting such services, as well as the moral hazard linked to the introduction of automatic access right: see ECB, 'Report of the ESCB on any Measure to Facilitate the Access of CCPs to Central Bank Liquidity Facilities' (2015).

${ }^{23}$ In line of principle, this description fits the current U.S. regulatory regime for third-country CCPs, embedded in the Commodity Exchange Act: See infra (n. 95)

24 See the G20 St Petersburg Declaration of September 2013, para. 71: "We agree that jurisdictions and regulators should be able to defer to each other when it is justified by the quality of their respective regulatory and enforcement regimes, based on similar outcomes, in a non-discriminatory way, paying due respect to home country regulatory regimes". See also the PFMI (n. 9), Responsibility E.
} 
entities. $^{25}$ Relocating clearing activities to the EU in view of Brexit would be costly both for individual institutions and for society given the outstanding market share of UK CCPs in OTC clearing, and would raise unprecedented legal challenges. Furthermore, the relocation of OTC clearing might be suboptimal in the long-run from a market efficiency perspective, while setting the conditions for new systemic concerns.

In order to continue servicing their EU clients, UK CCPs could either set-up subsidiaries in the EU or expand the activities of existing ones. ${ }^{26}$ The outcomes of similar strategies are not easy to predict. First, it is not sure whether one or more EU-based CCPs will be able to offer comparable prices and conditions of service, in terms of margining and funding. Second, scale economies make clearing subsidiaries more costly to run than, for example, banking subsidiaries given the fragmentation of the clearing pool within the relevant group.

Relocating the clearing infrastructure would also be challenging from a legal standpoint. Indeed, almost all OTC derivative contracts are currently negotiated and cleared pursuant to UK law, reflecting the preferences of market participants, possibly related to the certainty, resiliency and specialization of UK law, and the presence of experienced practitioners in the City of London. When considering relocation, one should therefore take account of the costs related to the setting-up and on-going management of new contracts. Moreover, it is unclear what will happen to the derivatives contracts that are still pending at

\footnotetext{
25 It is indeed difficult to precisely quantify the EU related clearing volumes, i.e. those derivatives contracts involving at least one EU counterparty. Indeed, the studies currently available do not deliver clear and univocal results. For example, the Commission estimates that between 7 and 30\% of IRS cleared in London involve an EU counterpart: see Commission, Impact assessment (n. 7). On the other hand, building on the initial margin distribution by clearing member location of four of the top European CCP's (all domiciled in London), Rahman shows that $60 \%$ of initial margins come from outside UK's borders: Rahman (n. 2), 290. See also the assessment of SwapClear's activity differentiated between EU and non-EU firms presented in the London Stock Exchange Group (LSEG) response to the European Commission proposal for a regulation amending EMIR (Part II Supervision of EU and third-country CCPs), 18, available at: https://www.lseg.com/sites/default/files/content/documents/Regulatory/2017/October/20171030_EMIR_Am endment_Part II_LSEG_Comment_paper_to_the_European_Commission.pdf.

26 The conditions for CCPs authorization are embedded in art. 14 EMIR. For already authorized CCPs, wishing to extend their offer to additional services, EMIR foresees a procedure for the extension of authorization: see art. 15. In both cases, pursuant to Title III of EMIR, the decisions are taken by the NCA, however with the involvement of the college of supervisors. The positive college's opinion shall be given no later than five months starting from the application's submission by the CCP.
} 
the time of Brexit and how the loss of EMIR recognition will impact on them, also in terms of exposures' calculation. ${ }^{27}$ Without a grandfathering provision, EU counterparts will be forced to close-out their positions and re-open similar ones at EMIR-compliant CCPs. However, transferring entire portfolios of derivatives will not be cost-free and the possibility of unwanted negative consequences on the dynamics of European liquidity and pricing of collateral should not be underestimated. ${ }^{28}$

Anecdotal evidence suggests that other cleared markets, such as the Repo market, which is an important funding source for banks active in the derivatives market, could relocate to the continent in advance of Brexit even in the absence of regulatory interference. ${ }^{29}$ However, repo transactions are different to OTC derivatives, for they normally are short-term (in some cases settling overnight) and their clearing is relatively fragmented amongst Member States, so that UK CCPs do not hold a monopolistic position in the relevant market. ${ }^{30}$ Moreover, infrastructural efficiencies in the settlement of repos related to the T2S system deliver cheaper settlement conditions in the EU than in the UK. ${ }^{31}$ In addition, while the derivatives market is of systemic relevance due to its concentration and sheer size, the repo

\footnotetext{
27 A non-negligible amount of OTC derivatives are characterized by long term maturities, so that contracts entered into before Brexit will still be open at the time of the withdrawal. See the OTC derivatives statistics elaborated by the Bank for International Settlement: https://www.bis.org/publ/otc hy1711.htm.

28 The simultaneous close-out of multiple positions would be highly demanding in terms of capital. On this specific point, some scholars argue that CCPs, due to their margining system, tend to transform credit risk into liquidity risk, thus creating the conditions for, or aggravating the consequences of, major liquidity shocks: see Pirrong (n. 2); Roe (n. 2); more recently, Rama Cont, 'Central Clearing and Risk Transformation' (2017) Norges Bank Working Paper 3.

${ }^{29}$ A repurchase agreement - or repo transaction - is a common form of short-term financing, whereby financial institutions sell and buy-back high-quality securities. The seller promises to buy-back the securities at a higher price at a given date, sometimes on an overnight basis. During the trade life, the securities are used as collateral for the trade. An analysis of Repos' clearing is out of the scope of the present paper. For an overview of the market for repo-transactions, including its dynamics during the 2008 financial crisis, see: Paolo Saguato "The liquidity dilemma and the repo market: a two-step policy option to address the regulatory void." Stan. JL Bus. \& Fin. 22 (2017): 85.

${ }^{30}$ Such a statement is supported by the industry data available. Compare for examples the volumes of Eurex, (http://www.eurexrepo.com/repo-en/info-center/statistics?frag=137780), LCH SA and LCH ltd, (https://www.lch.com/services/repoclear/repoclear-ltd/volumes ). LCH group is at present the main provider of Repo clearing services in the EU via its two CCPs located in France and in the UK.

31 Differently to its French sister company, LCH ltd is not entitled to access the benefits of T2S netting: see https://www.risk.net/derivatives/5341006/london-likely-to-lose-all-euro-repo-clearing-business.
} 
market is systemic per se, as central banks use it for purposes of monetary policy. ${ }^{32}$ Given the interplay between the repo market and derivatives' funding, it is not clear how the loss of colocation benefits would impact the latter, possibly aggravating the liquidity issues highlighted above.

Furthermore, a relocation of OTC derivatives clearing would possibly disrupt the value chain of clearing, i.e. the connections between the various layers of direct and indirect clearing, which play an essential role in respect of the access to CCP clearing by wholesale derivatives users. ${ }^{33}$ Given these complexities, switching derivative positions will no doubt require more time than that allowed under Art. 50. In the transitional time the transaction costs of clearing will likely go-up.

Apart from that, a relocation of the clearing industry could be suboptimal in terms of market efficiency, as the clearing landscape could fragment across reference currency zones leading to the formation of an EU-captive pool of liquidity, with a negative impact on clearing costs. ${ }^{34}$ Moreover, it is not sure that the clearing of non-euro derivatives will also move to the Eurozone, given the lack of liquidity and scale for the clearing of such products in the EU. ${ }^{35}$ If the execution price of a particular derivatives transaction is linked to the liquidity of the relevant clearing pool, in the context of a fragmented industry environment, separated across

\footnotetext{
32 Repo rates are used by central banks as channels of monetary policy implementation. Therefore, CCPs active in this market are of particular concern for central banks, in particular due to their margining system and haircut provisions, as they could interfere with the central bank's monetary policy.

33 The importance of generalized access to central clearing was recognized by the FSB since the beginning of the implementation of the G20 mandate: see OTC Derivatives Market Reforms: Third Progress Report on Implementation (2012), available at: http://www.fsb.org/wp-content/uploads/r_120615.pdf >. Indeed, indirect clearing arrangements are the preferred access option for many banks, possibly depending on the regulatory and prudential burdens that impact direct clearing members. However, as noted by the FSB, at present a limited number of global intermediaries dominate the market for client clearing. Clearly, this determines a strong dependence on them: see FSB (n. []) and also Benoît Cœuré, Member of the Executive Board of the ECB, 'Risks in central counterparties (CCPs)' (23 January 2014), speech held at the policy panel during the conference Mapping and Monitoring the Financial System: Liquidity, Funding, and Plumbing, Washington, available at http://www.bis.org/review/r140127c.htm.

34 Based on Swapclear's data, LSEG argued that the volumes to relocate would be relatively small, around $14 \%$ of SwapClear's activities. Moreover, the lower level of liquidity of the EU captive market would determine aggregate structural costs for EU firms under the form of worsened execution prices of approximately 25 billion \$ per year: see LSEG (n. 30 ), 19.

${ }^{35}$ See the state of the current European OTC market as depicted by the Commission, supra at n. 7.
} 
reference currency zones, market participants will incur higher costs and loose the benefits deriving from keeping their portfolio concentrated in a single CCP.

However, the creation of an EU-captive pool will not break the interdependencies between the EU and the UK financial systems, which should nonetheless remain highly interconnected. Interdependencies between EU and UK financial institutions will not be broken, but redesigned, possibly in a less transparent setting, and focussed on the banking system. One could argue, therefore, that the concentration and globalization of the clearing industry are natural trends that regulators should refrain from hampering on grounds of financial stability, as every effort in this direction would in the end be rather quixotic.

3. Role of politics in determining the impact of Brexit

In this section, we examine the regulatory and supervisory options which are available to the EU and the member States for determining the impact of Brexit on the clearing industry, such as recognizing UK CCPs under EMIR's equivalence regime; entering into a free trade agreement with the UK covering clearing services post-Brexit; reforming EMIR in order to strengthen supervision over third-country CCPs. In particular, we analyse the political dimensions of this topic, investigating why and how national interests and interest groups might work against the maintenance of the status quo and for the relocation of clearing activities to the Eurozone.

3.1 Equivalence is the regime to apply to third-country CCPs under existing regulation. ${ }^{36}$ According to Article 25 EMIR, a CCP established in a third country may provide clearing services to either clearing members or trading venues established in the Union

\footnotetext{
36 See art. 25 EMIR.
} 
provided that the Commission has adopted an equivalence decision and ESMA has recognized the CCP at issue. ${ }^{37}$ For the Commission to adopt a similar decision, the third country's legal and supervisory framework must be effective and ensure that CCPs comply with requirements equivalent to those under Title IV of EMIR. ${ }^{38}$ Once the third country's regime has been found equivalent, CCPs authorised under it may apply to ESMA for recognition. ${ }^{39}$ ESMA shall recognise a CCP only after consultation with the competent authorities, ${ }^{40}$ provided however that the CCP is subject to effective supervision and enforcement in the third country - including an equivalent system for anti-money-laundering and combating the financing of terrorism -41 and cooperation arrangements have been agreed between ESMA and the relevant third-country authority. ${ }^{42}$ Once recognised, the third-country CCP is entitled to provide clearing services to EU counterparts, which will benefit of its status as Q-CCP under CRR. ${ }^{43}$

However, the current equivalence regime presents downsides, which make the relevant process relatively cumbersome and unpredictable, and therefore less attractive for the UK CCPs than the single licence presently in force. First, this regime leaves room to

\footnotetext{
37 See art. 25 (3) and (7) EMIR.

38 See art. 25 (6) EMIR. The third country should also have in place an effective system for recognition of thirdcountry legal regimes.

${ }^{39}$ For a list of the third countries which have been deemed equivalent by the Commission, see https://ec.europa.eu/info/business-economy-euro/banking-and-finance/financial-markets/post-tradeservices/derivatives-emir en.

40 Art. 25 (3) indicates the authorities that ESMA is required to consult when assessing the conditions for recognition. They are the ones which would be part of the CCP supervisory college if the third-country CCP were domiciled in the EU under art. 18 EMIR.

${ }^{41}$ See art. 25 (2) d) EMIR.

42 See art. 25 (2) c) and (7). The latter states the minimum requirements that the cooperation agreement should cover. For a practical example of a Memorandum of Understanding between ESMA and a third country authority, see (n. 98) below.

43 In the context of the proposal for a review of the ESAs' competence, the EC suggested to amend current art. 33 of the Regulation establishing ESMA and expand its participation to the equivalence process. Under the proposed amendment, ESMA will assist the EC with technical advice in preparing the equivalence decision. The proposed amendment entrusts the authority with the responsibility of monitoring the regulatory and supervisory developments on an on-going basis, the enforcement practices in third countries for which the EC has adopted an equivalence decision, and the delivery of a confidential report on their findings to the Commission on an annual basis: see the proposed amendments to art. 33 of the Proposal for a Regulation of the European Parliament and of the Council amending Regulation 1095/2010, COM(2017) 536 final.
} 
discretion and political interference also considering the high stakes involved. ${ }^{44}$ Second, it should technically be invoked only after that the UK has become a third country, which would create a regulatory cliff-edge at the time of Brexit. In order to allow the UK CCPs to be recognized in advance of Brexit under a model of pre-emptive equivalence, the political consensus of the EU and its member States would be required. Third, the equivalence provisions raise concerns from a systemic perspective, as they do not foresee the ECB's active participation in the equivalence decision and in the recognition procedure, but assign a consultative role to the same. More generally, EMIR remains silent with regard to the need for mutual central banking support of third-country CCPs. ${ }^{45}$ Fourth, the equivalence framework is intrinsically unstable, for the Commission is entitled to revoke its equivalence decision at any time, for instance after changes to either the third-country's laws or the EU regulatory framework. As a result, it is arguable whether the present equivalence framework offers the legal certainty needed to adequately support the UK's clearing industry.

3.2 A bilateral trade agreement with the EU is another option, which has been endorsed by the UK government, while the EU position in this regard is still ambiguous. ${ }^{46}$ Such an agreement would entitle UK CCPs to access the EU single market post-Brexit under

\footnotetext{
44 If we look at past practices, we see the complexities which could stall an equivalence decision. The recognition of US CCPs offers an excellent example. When the EC assessment of US CCPs' regulatory framework began in 2012, it was clear that US and EU rules differed in technical details. However, EU and US regulators were apparently unable to say whether the two systems guaranteed similar outcomes. Negotiations advanced slowly, then stalled, and a deadline for an agreement was pushed-back twice in 2016. At one point, U.S. clearing providers, such as the Chicago Mercantile Exchange (CME), frustrated with the EU approach, called for EU firms to be barred from US CCPS. After four years, and only with the deadline for mandatory clearing hanging over EU counterparts, equivalence was granted by EU regulators to the US system. On that occasion, the EC and the CFTC in a joint statement agreed on a common framework for the supervision of transatlantic CCPs. The CME was then recognized by ESMA shortly afterward. See British Bankers Association, 'What is Equivalence and How Does it Work?' (2016) Brexit Quick Brief (4 <https://www.bba.org.uk/wp-content/uploads/2016/12/webversion-BQB4-1.pdf>

45 See supra n. 27.

${ }^{46}$ Before the start of the negotiating rounds, the British government issued a white paper disclosing the guiding principles of its negotiating strategy. The twelve principles should inspire the post-Brexit UK national and international actions: see H.M. Government, 'The United Kingdom Exit from and New Partnership with the European Union' (2017). The same was done by European authorities, see: European Council, Draft Guidelines Following the United Kingdom's Notification Under Art. 50 TEU (31 March 2017) and European Parliament, Draft Motion for a Resolution (29.03.2017), B8-0000/2017, Recital E.
} 
conditions similar to those presently enjoyed by them under the single passport. However, the negotiation of a trade agreement would no doubt be complex and require a relatively long time to be completed. Moreover, several conditions should be agreed upon as to the crossborder provision of financial services.

First, substantial divergence between the respective rulebooks should be avoided in the future, so as to allow the continuing mutual recognition of supervisory systems. ${ }^{47}$ This would require setting-up mechanisms for the mutual consultation between the two parties on regulatory developments, which should be similar in order to keep a level-playing field between the UK and the EU. Second, appropriate enforcement and dispute resolution mechanisms should be in place, so as to ensure the parties' compliance with the conditions and procedures foreseen by the trade agreement. Legal engineering would be required to reflect the specificities of the EU legal order, including the role and prerogatives of the European Court of Justice. ${ }^{48}$ Third, the agreement at issue should also cover the central banks' liquidity assistance to CCPs; however, it is not sure that this would be feasible given central banks' independence and in the absence of regulatory amendments attributing supervisory powers to the central banks of issue with respect to third-country CCPs (see sec. 4).

More generally, successful negotiations of a trade agreement depend on the political will of the parties involved, which would surely be influenced by a broad set of interests and values, such as those concerning the Treaty's fundamental freedoms. Furthermore, some member States (France and Germany in particular) would likely protect their own financial centres and clearing industry, objecting to the recognition of UK CCPs' access rights to the

\footnotetext{
47 Differences between the UK and EU rulebooks would definitely have an important impact on market participants. However, considering the high level of global convergence on international standards for CCPs and other financial market infrastructures (PFMI), the risk of divergence may be considered of minor impact.

${ }^{48}$ One point of serious concern regards the sui generis constitutional nature of the European Union, which may present unexpected challenges in relation to international dispute settlement systems. In particular, the principles stated in the ECJ's Opinion 2/13 of 18 December 2014, on the Accession to the European Convention for the Protection of Human Rights and Fundamental Freedoms (18 December 2014) make the drafting of a dispute settlement system more cumbersome. On this topic, see Stephan W. Schill, 'Editorial: Opinion 2/13-The End for Dispute Settlement in EU Trade and Investment Agreements?'(2015), The Journal of World Investment \& Trade 16(3), 379.
} 
single market and/or requesting conditions unacceptable to the UK. The high number of vetoempowered institutions involved in the negotiation procedures - such as the Council of the European Union, the European Parliament, the UK Parliament, the Member States' Parliaments and some regional Parliaments -49 could hinder the positive outcome of negotiations within the time allowed under Art. 50, even assuming an extension of the same. On the whole, the future of the OTC clearing industry is commingled with the fate of Brexit negotiations, which presently remains difficult to predict. After six intense negotiating rounds from June to November 2017, the negotiating parties have reached preliminary consensus ${ }^{50}$ on the first block of topics, including citizens' rights, the EU-UK border in Northern Ireland and a procedural framework for the financial settlement. ${ }^{51}$ The Commission has concluded therefore that sufficient progress has been made in the first phase of negotiations and has endorsed a positive decision by the European Council. ${ }^{52}$ On the 20 December, the European Council gave the Commission a mandate to complete the negotiations on the remaining issues, which concern the new framework of the EU-UK relationship..$^{53}$ Furthermore, the EU Council welcomed the Commission's proposal to address the topic of a transitional arrangement in the

\footnotetext{
${ }^{49}$ Evidence from the EU past undertakings in the field of external trade policy already highlighted that the participation of regional Parliaments, provided in certain Member States' constitutions, can sometimes add a remarkable degree of unpredictability to the ratification process. The Walloon resistance in the case of the CETA agreement offers a good example, see: Arthur Beesley, 'Belgium sinks EU-Canada trade deal after Wallonia veto' (24 October 2016) Financial Times, available at: https://www.ft.com/content/a614ae5c-99f4-11e6-b8c6$\underline{568 a 43813464}$.

${ }^{50}$ However, what was agreed so far by the negotiating parties has not yet been translated into any legally binding commitment.

${ }^{51}$ See Commission, Joint report from the negotiators of the European Union and the United Kingdom Government on progress during phase 1 of negotiations under Article 50 TEU on the United Kingdom's orderly withdrawal from the European Union, available at https://ec.europa.eu/commission/publications/joint-reportnegotiators-european-union-and-united-kingdom-government-progress-during-phase-1-negotiations-underarticle-50-teu-united-kingdoms-orderly-withdrawal-european-union en.

52 See Commission, Recommendation for a Council Decision supplementing the Council Decision of 22 May 2017 authorising the opening of negotiations with the United Kingdom of Great Britain and Northern Ireland for an agreement setting out the arrangements for its withdrawal from the European Union, COM(2017) 830 final, available at https://ec.europa.eu/commission/publications/commissions-recommendation-includingsupplementary-negotiating-directives en

53 See European Council, (Art. 50) guidelines for Brexit negotiations, 15 December 2017, (EUCO XT 20011/17), available at: http://www.consilium.europa.eu/en/press/press-releases/2017/12/15/european-council-art-50guidelines-for-brexit-negotiations/
} 
early phase of the second round of negotiations. ${ }^{54}$ Under this arrangement the UK would still remain subject to the entire EU acquis, while as a third country would no longer participate in, nominate or elect members of EU institutions, nor participate in the decision-making of Union bodies, offices and agencies. ${ }^{55}$ Furthermore, the transitional period should be limited in time, not exceeding a period of two years.

However, the fate of negotiations is still uncertain. The complexity of the issues within the phase 2 agenda, such as the governance provisions of a transitional agreement and a holistic framework for future relationships, will possibly require even greater diplomatic skills and effort. There is also divergence as to Single Market access. Throughout the whole process, EU institutions and Member States have emphasized the need to guarantee the integrity of the Single Market and to preserve the EU regulatory autonomy. They also expressed the will to maintain the current level of EU standards on matters like fair competition, state aid, tax dumping and social and environmental responsibility. ${ }^{56}$

As a result, the UK would have small room to deviate from EU financial services regulation and to exercise standalone regulatory initiatives in other, non-directly linked sectors where it could have won important benefits as autonomous jurisdiction. ${ }^{57}$ Furthermore, the UK would have no voice in the decision-making process. Similar comments were recently made by Mr. Barnier, the Commission's chief negotiator, just after the adoption of the European Council's decision ${ }^{58}$ muting the enthusiasm raised by the latter. He also underlined that no European bilateral deal presently includes provisions on financial services granting a passport to the Single Market.

\footnotetext{
54 Ibid, (3).

55 See Commission, Communication from the Commission to the European Council (Article 50) on the state of progress of the negotiations with the United Kingdom under Article 50 of the Treaty on European Union, $\operatorname{COM}(2017) 784$ final, Conclusions. Prime Minister may had already endorsed the case for a transitional arrangement during her Florence speech, see infra n. 76.

56 Ibid (n. 64), (7). See also European Council (n. 56).

57 For example, as to initiatives in external UK trade policy.

58 See Commission, Speech by Micheal Barnier at the Trends Manager of the Year 2017 event (9 January 2018) Brussels.
} 
EU institutions and Member States were so far remarkably aligned in their approach to negotiations. However, national interests could influence future negotiations and make a sound and unanimous position more difficult to reach. The EU Parliament and the Council apparently share a common position. ${ }^{59}$ They will not let the UK cherry-pick amongst the Treaty's fundamental freedoms, also to discourage similar attempts by other EU countries. However, some Member States (France and Germany in particular) have strategies in place directed to ease the relocation of Euro-derivatives' CCPs (and more generally of UK-based financial institutions) to the Eurozone, so as to foster their own financial centres. ${ }^{60}$ Also the ECB will play a key role as to the relocation of euro-derivatives clearing to the Eurozone, as already shown by the same when adopting the relocation policy which was found ungrounded by the ECJ. A similar policy could appear as justified on legal grounds once the UK CCPs have become third-country institutions. ${ }^{61}$

Nonetheless, other Member States, which do not derive special benefits from Brexit and fear the damages ensuing from a no-deal solution could lobby for a more pragmatic and less punitive approach. ${ }^{62}$ Especially non-Euro countries, such as Sweden and Denmark, the positions of which sometimes coincided with those of the UK on certain topics, could be keener on pragmatism, also to prevent an excessive consolidation of political power of the

${ }^{59}$ See European Council, 'Draft Guidelines Following the United Kingdom's Notification Under Art. 50 TEU' (n. 56) and European Parliament, 'European Parliament Draft Motion for a Resolution' (n. 56).

60 The Autorité des Marchés Financieres (AMF) recently launched a dedicated welcome program for UK financial firms, aimed at easing the burdens of their relocation, called Agility: see

http://www.amf-france.org/en US/Actualites/Communiques-de-presse/AMF/annee-

2016.html?docId=workspace\%3A\%2F\%2FSpacesStore\%2F3ba641b9-c2f7-48a0-bd2c-6814bab06c88.

Meanwhile in Germany, a prominent officer at BaFin, the German financial supervisor, recently disclosed their willingness to approach the consequences of Brexit, i.e. the relocation and consequent authorization of relevant financial institutions in Germany, with pragmatism: see BaFin, Brexit - BaFin Chief Executive Director Raimund Röseler: "We are thinking pragmatically, but we will not accept empty shells", available at: https://www.bafin.de/SharedDocs/Veroeffentlichungen/EN/Fachartikel/2017/fa bj 1710 Brexit en.html.

${ }^{61}$ Moreover, initiatives aimed at building solid ground for ECB's powers over CCPs are already in place, as we highlight below at sec. 4 .

${ }^{62} \mathrm{~A}$ recent survey on the Member States' approaches to Brexit has highlighted that, given their heterogeneity, some may have diverging interests and expectations regarding the relationship with the UK in a post-Brexit world. For instance, firms in some countries, like the Netherlands and Luxembourg, presently have huge investments in the UK, while others have a remarkable number of their own citizens in the UK. In the case of Ireland, a hard border with the UK could reignite old conflicts. In similar cases, a no-deal exit would be matter of concern. See Eleonora Poli, "Mapping Member States' Stances in a Post-Brexit European Union" (2016) Istituto Affari Internazionali Working Papers 16. 
Eurozone States.63 The need for Member States to individually ratify the withdrawal agreement in compliance with their constitutional provisions may exacerbate those conflicts.

In the second round of negotiations, the UK government will need to reconsider, partially at least, its guiding principles for the new framework of future relationships with the EU. ${ }^{64}$ The recent opening of Prime Minister May in her speech in Santa Maria Novella, to an extension of the transitional period with full acceptance of the EU acquis, including the ECJ jurisdiction, may indicate a prise de conscience. ${ }^{65}$ However, she may not have the power to adequately sustain the political bargaining, as hard brexiteers, disappointed by the terms agreed so far, heat the tones up, sponsoring a no deal exit. Therefore, it is doubtful that the final proposal coming out of the negotiations will have the back-up of her own party. Yet, it is even more unlikely that the UK will accept a humiliating deal, so that a no-deal solution cannot be excluded.

3.3 A third option, which would ease maintaining the status quo without ruling out the possibility of a free trade agreement, is a reform of EMIR enhancing the surveillance over third-country clearing providers under the equivalence and recognition regime already in force. A similar reform would require a new regulation to be adopted through co-decision procedure by the Commission, the Council and the European Parliament, and would likely be exposed to intense political bargaining. The Commission has recently published a proposal to this effect, suggesting amendments of EMIR's supervisory framework relating to thirdcountries' CCPs. ${ }^{66}$ The proposed amendments are clearly Brexit-driven, while being linked to

\footnotetext{
${ }^{63}$ No doubt, Brexit will represent a milestone also for the EU internal governance, as the political weight of the Eurozone Member States will increase.

${ }^{64}$ See before (n. 56).

65 See the PM's Florence speech, "A new era of cooperation and partnership between the UK and the EU", available at: https://www.gov.uk/government/speeches/pms-florence-speech-a-new-era-of-cooperation-andpartnership-between-the-uk-and-the-eu .

66 See Recital 27 of the Commission's 'Proposal for a Regulation of the European Parliament and of the Council amending Regulation (EU) no 1095/2010 establishing a European Supervisory Authority and amending Regulation (EU) No 648/2012 as regards the procedures and authorities involved for the authorization of CCPs
} 
a broader context of pending legislative initiatives pertaining to CCPs. ${ }^{67}$ In fact, they also touch upon the supervision of EU-based CCPs, which would become semi-centralised through the institution of a new supervisory body identified as the CCP Executive Session within ESMA's Board of Supervisors. 68

Tying-up the supervision over third-country CCPs with the partial centralization of supervision over EU CCPs, while appearing as consistent and grounded on sound reasons, ${ }^{69}$ may complicate the political games regarding EMIR's reform. Indeed, the treatment of thirdcountry CCPs should be particularly concerned with the impact of Brexit and therefore attracts the kind of arguments which are usually employed either pro or against the maintenance of the status quo of the clearing industry post-Brexit. On the one side, efficiency reasons may justify maintaining the present location of OTC derivatives CCPs in London, while recommending some form of supervision by EU institutions and authorities. On the other, stability concerns may rather justify stricter requirements of EMIR with respect to the supervision over third-country CCPs, at the margin incentivising the re-location of the relevant industry to the EU post-Brexit.

The supervision of EU CCPs is a different question and its enhancement would see different constituencies acting either pro or against it. While centralisation of supervision in ESMA would satisfy stability concerns and therefore represent a sound policy for the EU, the NCAs would likely resist it in order not to lose supervisory powers. The national governments

and the requirements for the recognition of third-country', COM (2017) 331 final. The open consultations on the proposal were closed as of the 30 of December.

67 To be true, the EMIR review project consists of two proposals. The one not yet cited is dubbed as EMIR Refit: see Proposal for a Regulation of the European Parliament and of the Council amending Regulation (EU) No $648 / 2012$ as regards the clearing obligation, the suspension of the clearing obligation, the reporting requirements, the risk-mitigation techniques for OTC derivatives contracts not cleared by a central counterparty, the registration and supervision of trade repositories and the requirements for trade repositories, COM

${ }^{68}$ See on this point: Danny Busch 'A Stronger Role for the European Supervisory Authorities in the EU27' in Danny Busch, Guido Ferrarini, and Emilios Avgouleas (eds) Capital Markets Union in Europe (Oxford: OUP, 2018).

${ }^{69}$ In comparison with the U.S., the current EMIR supervisory arrangements present a dualism between EU authorities, which are competent in respect of third countries CCPs, and Member States national authorities, which are competent for EU domiciled ones. 
would act accordingly, out of worries about their fiscal responsibilities. As to the industry, some CCPs may find the concept of a single supervisor as instrumental to creating a level playing field, while others may prefer to retain the current NCA regime, depending on the products that they offer, their clearing volumes and the clearing members base. ${ }^{70}$ All this might in the end suggest keeping the two areas of discussion on EMIR's reform separate, so as to focus on Brexit in the discussion about third-country CCPs, while leaving centralised supervision over CCPs to the more general discussion on the reform of ESMA.

\section{Reforming EMIR so as to protect EU financial stability}

In each of the options examined in the previous section, politics play a role. In the equivalence regime, discretion offers some room for political influence. The negotiation of a trade agreement by definition requires consensus to be reached by the EU and the UK government. EMIR's reform must undergo a co-decision procedure where several EU institutions have veto powers. In this section, we further explore this third option, which could either help maintaining the status quo of the clearing industry or force its disruption depending on the regulatory solutions adopted.

The proposal of the Commission for EMIR's reform introduces a new binary classification of third-country CCPs, distinguishing between those that do not pose a material risk to the EU financial stability and those that presently are or are likely to become systemically relevant. ${ }^{71}$ Whilst the former - dubbed as Tier one CCPs - would be subject to the current recognition requirements under Article 25 EMIR, Tier two CCPs would undergo an

\footnotetext{
70 For analysis of the different opinions in the industry, see the responses to the Commission's consultation on EMIR review: https://ec.europa.eu/info/law/better-regulation/initiatives/com-2017-331 en.

71 One fundamental element of the proposed binary classification regards the scope of the assessment of the systemic nature of the CCP, which under the current proposal would be made at CCP level and not at clearing service or asset class level. Indeed, the Commission did not make any reference to the possibility to evaluate the systemic nature of third-country CCPs at clearing service or asset class level: see Impact assessment, 60. This approach has been criticized by some market participants, which underlined its lack of granularity, suggesting a more proportionate assessment at clearing service level. See the LSEG (n. 30), 11.
} 
enhanced regulatory framework consisting of a sliding scale of (additional) prudential requirements, which are proportional to the risks posed by the $\mathrm{CCP}$ at issue to EU financial stability. ${ }^{72}$ Tier two CCPs would be recognized by ESMA on the condition that they comply with the requirements specified in Title IV and V of EMIR.73 Moreover, CCPs should comply with other requirements foreseen by the relevant central bank of issue. ${ }^{74}$ ESMA shall be responsible for the on-going supervision of Tier 2 CCPs, which shall be exercised in accordance with the relevant central bank for those decisions that could interfere with its monetary policy tasks. ${ }^{75}$ The Commission's proposal also equips the authority with the necessary tools for performing the tasks assigned by the new regulation, such as inspection powers and the right to impose fines in cases of non-compliance by the supervised entity. ${ }^{76}$ However, where these additional requirements did not sufficiently assure the EU financial stability, ESMA could recommend the Commission to adopt an individual location decision, declaring that the scrutinized CCP may provide clearing services only by relocating its activities inside the EU. Like in the present equivalence regime, the process would involve a certain degree of discretion.

The location decision would therefore represent a last resort measure to be implemented when the risks posed by an individual CCP are deemed not to be otherwise

\footnotetext{
72 ESMA shall determine whether a CCP is systemically important, or likely to become, applying the criteria specified in art. 25 (2a). The Commission will further specify the conditions of the assessment via a delegated regulation.

73 See the proposed art. 25 (2b), a).

${ }^{74}$ See art. 25 (2b) b). The proposal does not specify the requirements that a central bank may be entitled to impose on the CCP, however their scope should be related to the monetary policy responsibilities of the former, therefore covering areas related to stress testing, liquidity and collateral arrangements and possibly also the opening by the CCP of a cash account with the relevant central bank.

${ }^{75}$ See the proposed art. 25b. ESMA shall assess the compliance of Tier 2 CCPs with the requisites specified in art. $25 \mathrm{~b}$ at least on a yearly basis. Moreover, pursuant para (2), ESMA shall prepare and submit draft decisions to the relevant central bank of issue in some specific cases and also obtain the consent of the latter as the aspects of those decisions relating to the carrying out of the central bank's monetary policy tasks.

${ }^{75}$ See the proposed art. 25b. ESMA shall assess the compliance of Tier 2 CCPs with the requisites specified in art. $25 \mathrm{~b}$ at least on a yearly basis. Moreover, pursuant para (2), ESMA shall prepare and submit draft decisions to the relevant central bank of issue in some specific cases and also obtain the consent of the latter as the aspects of those decisions relating to the carrying out of the central bank's monetary policy tasks.

${ }^{76}$ See the proposed art. 25c [Request for information], art. 25d [General investigations], art. 25e [Onsite inspections].
} 
manageable. Surely, the proposal is a step forward in strengthening ESMA and especially central banks' supervision and monitoring of EU financial stability in respect of third-country CCPs. However, the proposed reform is open to criticism on various counts. First, thirdcountry CCPs would be subject to double compliance and therefore experience additional costs with respect to EU CCPs, which would make the playing field for OTC derivatives clearing in euros unlevelled. To be true, the Commission's proposal foresees a waiver allowing for substitute compliance, which would limit the costs at issue, but much is delegated to level 2 measures, which should specify both the minimum elements and the practical modalities and conditions. ${ }^{77}$ In any case, the waiver mechanism is subject to the risk of conflicting rules in different jurisdictions. ${ }^{78}$

Second, ESMA's power to adopt a location decision is more proportionate and "lighttouch" than the location policy once adopted by the ECB, but is still disruptive and could determine unintended consequences. UK CCPs will need to confront themselves with an (implicit) threshold for third-country clearing providers, which may incentivize them not to expand their volumes in order to avoid the relocation trigger, despite the fact that the clearing's economy naturally strives for scale and size. Alternatively, they will face relocation measures by ESMA, which in fact is not very different to imposing these measures ex ante by regulatory fiat. ${ }^{79}$

The extraterritorial application of new EMIR should also be considered by asking how third countries other than the UK will react to the proposed amendments. ${ }^{80}$ The enforcement of a strict location policy has in fact few international precedents and sensibly deviates from

\footnotetext{
77 See art. 25a. The CCP may request ESMA to assess whether the conditions for comparable compliance are met. The CCP's request shall provide all the necessary factual elements upon which the ESMA's assessment should be based.

${ }^{78}$ See the response by the Chicago Mercantile Exchange to the Commission's consultation regarding the EMIR review, advocating the benefits of an outcome-based deference system: supra at n. 81 .

${ }^{79}$ The granularity of the location decision will reflect the scope of the assessment of systemic importance, hence targeting the CCP rather than its clearing services: see before (n. 82).

80 This consideration also applies in respect to the recent proposal of the ECB for an amendment of art. 22 of the $\mathrm{E}(\mathrm{S}) \mathrm{CB}$ statute and also to the Commission's opinion: see further in this section.
} 
the relevant international regulatory principles deriving from the original G20 commitment, which sponsor an outcome-based equivalence assessment, deference and cooperation between relevant authorities. ${ }^{81}$ The U.S. may serve as case study. ${ }^{82}$ The EC and the CFTC agreed to a common regulatory approach for transatlantic CCPs, based on deference. ${ }^{83}$ Ironically, on that occasion the CFTC and EC jointly underlined that "derivatives markets are global in nature. A common approach to their regulation and supervision is critical to supporting cross border activity and maintaining financial stability". 84 A reform of the equivalence provision would imply a unilateral renegotiation of the terms agreed in 2016, which could lead to U.S. countermeasures. ${ }^{85}$ Cross-border FMIs groups would consequently be impacted. 86

However, changes in the proposed amendments should be expected. The European Parliament has issued a Draft Report on the proposal and its Rapporteur, Miss Danuta Hübner, who is also chair of the Constitutional Affairs Committee in the EU Parliament, has recently declared that attention should be brought to the discretion envisaged for the authorities involved in the location decision, advocating stricter conditions for regulators to determine whether clearing facilities should be relocated or not. ${ }^{87}$

\footnotetext{
${ }^{81}$ See the PFMI (n. 9), Responsibility E.

${ }^{82}$ It is useful to compare the proposed EMIR framework with the one presently in force in the U.S. applicable to third-country CCPs. The Dodd-Frank Act amended the Commodity Exchange Act so as to require a non-U.S. CCP to register with the CFTC as a Derivatives Clearing Organisation (DCO) if it performs clearing services in the U.S. or to U.S. clearing members and customers. In the absence of these conditions, registration with the CFTC is not required even to CCPs which clear a considerable amount of transactions in US dollars. Moreover, the CFTC makes an extended use of deference, thus limiting the compliance burden for intercontinental CCPs. See the speech by the CFTC Chairman J. Christopher Giancarlo to the Eurofi Financial Forum in Tallin (14 September 2017), available at: http://www.cftc.gov/PressRoom/SpeechesTestimony/opagiancarlo-28.

83 Chicago Futures Trading Commission and European Commission, A common approach to transatlantic CCPs, available http://www.cftc.gov/idc/groups/public/@newsroom/documents/speechandtestimony/eu cftcstatement.pdf 84 Ibid, 1.

85 The proposal would probably have consequences on the current arrangements between ESMA and the CFTC, as set in in the Memorandum of Understandings between the authorities agreed pursuant art. 25 EMIR. The full text of the MoU is available at http://www.cftc.gov/PressRoom/PressReleases/pr7384-16

${ }^{86}$ A vicious circle of extraterritorial application of law would lead to the balkanization of financial markets: see Philip Stafford and Jim Brunsden, 'Washington warns against EU location policy' (10 May 2017), Financial Times.

${ }^{87}$ See European Parliament, Draft Report on the proposal for a regulation of the European Parliament and of the Council amending Regulation (EU) No 1095/2010 establishing a European Supervisory Authority (European
} 
Moreover, it is not clear how the Commission's proposal would interact with the proposed amendment of article 22 of the ECB statute, which was recommended by the ECB on the first of July 2017.88 This amendment, once adopted, would grant the ECB regulatory powers over clearing infrastructures, therefore covering the competence gap which was recognised in the location policy judgement. ${ }^{89}$ As stated by the ECJ, an amendment to Article 22 represents a precondition for the ECB to exercise the powers which would be awarded to the same under the new equivalence and supervisory framework. The EMIR review and the proposed new Article 22 would promote a supervisory role of the Central Banks of Issue in respect of CCPs consistently with the monetary policy tasks of the $\mathrm{E}(\mathrm{S}) \mathrm{CB}$, given that the margin and collateral requirements established by CCPs may have a significant impact on monetary policy.

Nonetheless, the proposed amendment would confer broad discretion to ESCB members in the regulation of both EU domiciled and third country CCPs, even broader than that envisaged under the new EMIR proposal. This leads to consider the consistency between the scope of the new ECB powers and the EMIR framework, as done by the EC which proposed a new drafting of the Article 22 amendment, adding a clear reference to the condition that the exercise of such powers should be exercised consistently with the acts adopted by the European Parliament and the Council, as well as with the relevant implementing measures. ${ }^{90}$

\footnotetext{
Securities and Markets Authority) and amending Regulation (EU) No 648/2012 as regards the procedures and authorities involved for the authorisation of CCPs and requirements for the recognition of third-country CCPs. (COM(2017)0331 - C8-0191/2017 - 2017/0136 (COD)).

${ }^{88}$ See Recommendation for a Decision of the European Parliament and of the Council amending Article 22 of the Statute of the European System of Central Banks and of the European Central Bank (ECB/2017/18). The proposed amendment reads as follows: "The ECB and national central bank may provide facilities, and the ECB may make regulations, to ensure efficient and sound clearing and payment systems, and clearing systems for financial instruments, within the Union and with other countries"

${ }^{89}$ See above sec. 2.

${ }^{90}$ See the Commission's Opinion of 3.10.2017 on the Recommendation of the European Central Bank for a Decision of the European Parliament and of the Council amending Article 22 of the Statute of the European System of Central Banks and of the European Central Bank, Com(2017)6810 final. Instead of rewording paragraph (1) of art. 22, the EC proposed to add the following second paragraph: "To achieve the objectives of the ESCB and to carry out its tasks, the ECB may make regulations regarding clearing systems for financial instruments within the Union and with third countries, consistent with acts adopted by the European Parliament and the Council and with measures adopted under such act."
} 
However, one could object that the introduction of an explicit reference to a consistency obligation with other EU institutions legal acts, clearly intended to limit ECB's discretion, would introduce a change in the relationship between the ECB and the other Union Institutions, de facto subordinating the powers of the former to the acts adopted by the latter. Therefore, the proposal could raise some doubts in relation to the hierarchy of the Union's legal acts, while at the same time being in contrast with Article 130 TFEU on the ECB's independence from the Union Institutions. ${ }^{91}$ Nevertheless, without an amendment introducing a clear reference to its competence in relation to clearing systems under the current ES(C)B statute, the ECB would paradoxically lack the competence to exercise the powers provided for in the new EMIR supervisory framework, as already highlighted by the ECJ. A redrafting of the amendment should therefore be duly considered. ${ }^{92}$

A review of EMIR, possibly in the direction that we propose in this section and the ancillary modification of Article 22 of the E(S)CB Statute, which would empower relevant central banks to exercise the powers envisaged under the amended EMIR, are both necessary - but not sufficient - steps in order to guarantee the soundness of the clearing infrastructures in light of the upcoming Brexit. Indeed, the adoption of an holistic European framework for CCP recovery and resolution, including special provisions regulating the case of third country CCPs, which offer services to EU counterparties, would be a natural complement to the current EMIR review process and would in general consolidate the soundness of the supervisory and regulatory framework applicable to CCPs, similarly to initiatives already adopted in other financial sectors. ${ }^{93}$ Furthermore, besides the clear benefits in terms of financial stability, the adoption of a European framework of CCPs' recovery and resolution

\footnotetext{
91 The ESCB statute is a source of primary EU legislation, like the fundamental treaties, whereas the EP and Council regulations are pieces of secondary legislation. The Commission's wording would appear to subvert the hierarchy of EU legal sources.

${ }^{92}$ In theory, the limits and guarantees as to the exercise of the ECB's powers over CCPs should be included in the same legal act grounding these powers, i.e. the ESCB statute.

${ }_{93}$ Not surprisingly, this issue has been widely debated amongst regulators in international for a like the FSB and IOSCO: see (n. 10).
} 
would bring a meaningful contribution to the enforcement of a regulatory EU level playing, which is presently lacking in this area. ${ }^{94}$ In principle, an appropriate framework should be efficient, effective, non-discriminatory and ensure the soundness of the financial systems while avoiding to the widest extent possible the recourse to taxpayers' money. Relevant authorities should be given the necessary tools and related flexibility, so as to prevent and eventually manage the consequences of a turmoil affecting a CCP.95 Moreover, given Brexit, said framework should pay special attention to third-country CCPs, which provide clearing services to EU counterparts and are of systemic importance to the EU. An ideal framework should guarantee appropriate conditions for cooperation and information exchange between EU and relevant third-country authorities, while also setting-up an adequate mechanism for the mutual recognition and swift enforcement of resolution decisions.

A Commission's proposal of a EU regulation on CCP recovery and resolution is currently under discussion. ${ }^{96}$ Title VI of this proposal tackles the topic of third countries' CCPs and related agreements with third countries. ${ }^{97}$ Article 77 would require EU authorities to conclude cooperation arrangements with relevant third countries, specifying the minimum requirements they should touch upon. ${ }^{98}$ The proposal also mandates the exchange of confidential information with third-country authorities, provided certain conditions are

\footnotetext{
${ }^{94}$ Member States have adopted different solutions in respect of this topic. France and Germany require CCPs to obtain a banking license and make the banking resolution framework applicable to them. Italy has a system of special administration and compulsory administrative liquidation in place for CCPs. Interestingly, the only jurisdiction having a framework for recovery and resolution in place for CCPs is the UK. See Commission, Impact Assessment accompanying the Proposal for a Regulation of the European Parliament and of the Council on a Framework for the Recovery and Resolution of Central Counterparties and amending Regulation (EU) No 1095/2010, (EU) No 648/2012, and (EU) 2015/2365' COM (2016) 0856 final, COD (2016) 0365 final 28.11.2016. , at 12 .

95 See the FSB Key attributes as amended in 2014 (n.10).

${ }^{96}$ See 'Proposal for a Regulation of the European Parliament and of the Council on a Framework for the Recovery and Resolution of Central Counterparties and amending Regulation (EU) No 1095/2010, (EU) No 648/2012, and (EU) 2015/2365' COM (2016) 0856 final, COD (2016) 0365 final 28.11.2016. However, an extended analysis of this proposal is out of the scope of the present research.

97 Title VI may apply if one of the following conditions is met: (1) a third country CCP provides services or has subsidiaries in one or more Member States (2) a CCP established in a Member State provides services or has one or more subsidiaries in a third country: see art. 74 (1) and art. 77 (2). See also the wording of Recital no. 73.

98 See art. 77. Competent authorities shall conclude the cooperation arrangement taking into account the ones already established pursuant EMIR. Furthermore, para. (3) and para (4) specify the matters which respectively should be included or may be included in the arrangement.
} 
met. ${ }^{99}$ In addition, the proposal sets-up a framework for the recognition and enforcement of third-country resolution proceedings, specifying the cases where national authorities may exceptionally refuse to do so. ${ }^{100}$ Moreover, the regulation leaves the possibility open for European authorities to negotiate an agreement pursuant art. 218 TFUE, which could regulate the topic, in particular the mechanism for mutual recognition and enforcement of resolution procedures and also the processes of cooperation and information exchange. ${ }^{101}$ Clearly, the proposal is far from being at the end of its legislative iter and may be further amended. Nevertheless, the current set-up of Title VI addresses the topic of recovery and resolution of third-countries CCPs in a way that protects financial stability.

\section{Concluding remarks}

In this paper, we have essentially explored whether OTC derivatives clearing for EU counterparties should remain in London or relocate to the EU. Our answer has been rather straightforward: market participants (clearing counterparties and CCPs) should take the relevant decisions based on the transaction costs of OTC derivatives clearing, within an appropriate regulatory framework and in the absence of political interference. Nonetheless, we are aware that politics will play a role in each of the options examined in the paper for maintaining the status quo of the clearing industry in London, i.e. the equivalence regime, a trade agreement and a reform of EMIR. Moreover, the perspective of a trade agreement

\footnotetext{
${ }^{99}$ See art. 78. EU and national authorities should exchange sensitive information with third-country authorities only if the information concerned is necessary for the performance of the duties of the third-country authority, which should be deemed comparable to those established under the proposed regulation. The third-country authority is subject to stringent standards of professional secrecy at least equivalent to those applicable to EU authorities. Interestingly, the assessment of the first condition shall be considered as given if all the authorities of the Member States involved reach a unanimous position. Also, it is foreseen that third-country authorities may be invited to take part in resolution colleges as observers, but only in the case of discussion pertaining to crossborder enforcement issues: see art. 4 (4).

100 Art. 76 provides for cases where relevant national authorities are justified not to recognize third-country resolution proceedings, for example where systemic implications or a material fiscal impact may arise in their jurisdiction following to the recognition of a third-country decision.

101 See art. 74. The Commission may submit a recommendation to the Council for the negotiation of an agreement pursuant to art. 218 TFUE. This agreement may derogate to the provisions embedded in Title VI. Indeed, Title VI shall apply unless and until an international agreement with the third country enters into force: see articles 75 (1) and 77(1).
} 
between the EU and the UK covering financial services is at the moment uncertain, whereas a reform of EMIR is needed for financial stability reasons and should be swiftly carried out with the objective of strengthening the regulatory and supervisory framework applicable to thirdcountry CCPs. To this end, however, the Commission's proposal should be amended along the lines suggested in this paper and any location policy or similar requirement should be avoided for the reasons already explained. 


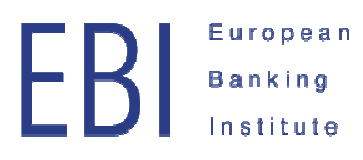

$\underline{\text { Address }}$

European Banking Institute eV.

Mainzer Landstrasse 251

60326 Frankfurt am Main

Germany

For further information please visit our website www,ebi-europa.eu or contact us at info@ebi-europa.eu 
The European academic joint venture for research in banking regulation

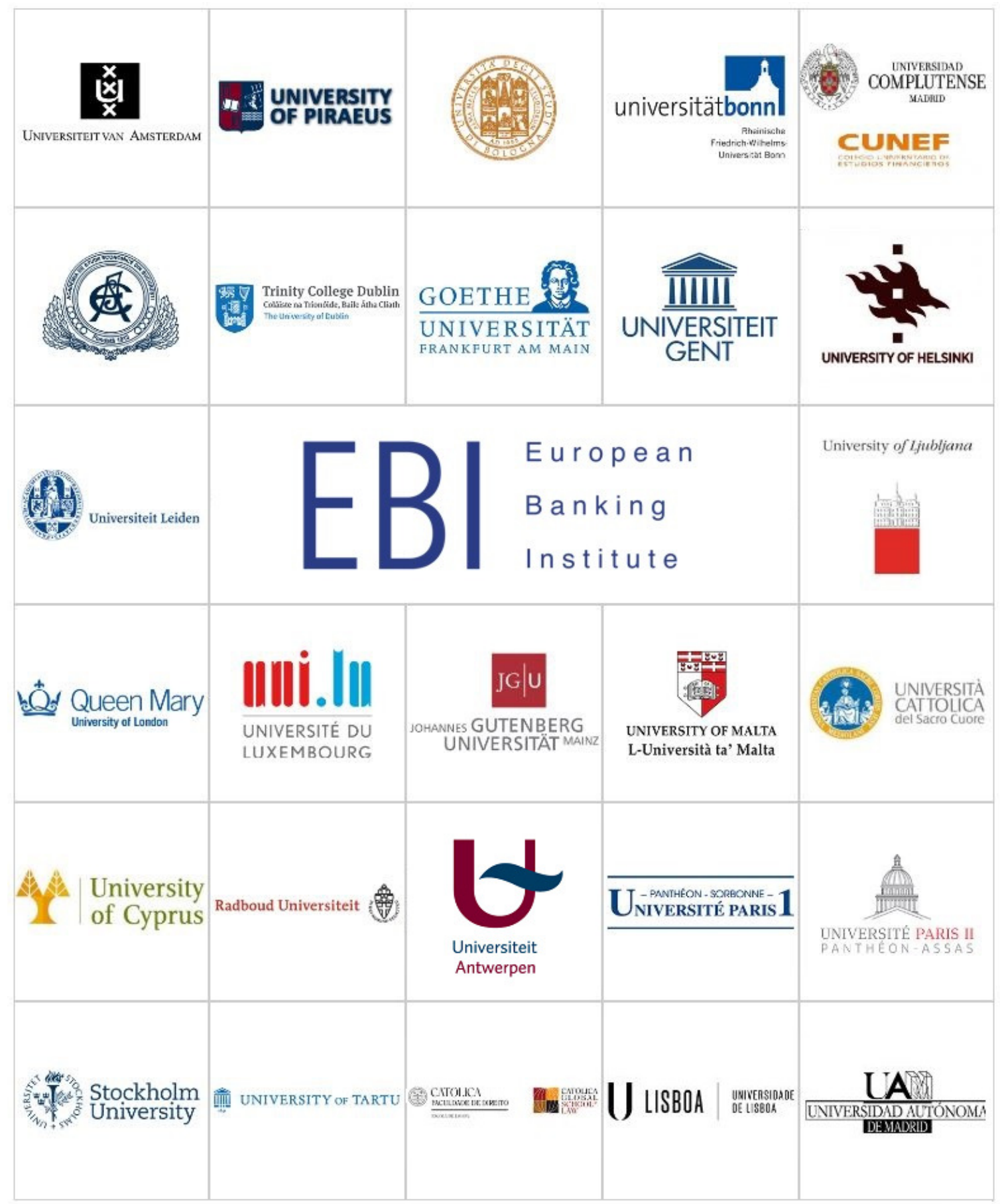

